\title{
DURABILITY ASSESSMENT OF BENDING STRUCTURES MADE OF NONLINEAR ELASTIC MATERIAL
}

\author{
Vladilen V. Petrov ${ }^{1,2}$, Roman V. Mishchenko ${ }^{1,2}$, Dmitry A. Pimenov ${ }^{1,2}$ \\ ${ }^{1}$ Yuri Gagarin State Technical University of Saratov, Saratov, RUSSIA \\ ${ }^{2}$ Research Institute of Building Physics of the Russian Academy of Architecture and Construction Sciences, Moscow, \\ RUSSIA
}

\begin{abstract}
Experimental studies and field tests indicate that the effect of corrosive media leads to significant changes in the physical and mechanical characteristics of structural materials. The article proposes a mathematical model that allows predicting the negative impact of aggressive media and assessing the durability of bent structures.
\end{abstract}

Keywords: nonlinear elastic material, induced heterogeneity, aggressive environment, mathematical model, surface corrosion, durability

\section{ОЦЕНКА ДОЛГОВЕЧНОСТИ ИЗГИБАЕМЫХ КОНСТРУКЦИЙ ИЗ НЕЛИНЕЙНО ДЕФОРМИРУЕМОГО МАТЕРИАЛА}

\author{
В.В. Петров ${ }^{1,2}$, Р.В. Мищенко ${ }^{1,2}$, Д.А. Пименов ${ }^{1,2}$ \\ ${ }^{1}$ Саратовский государственный технический университет имени Гагарина Ю.А., г. Саратов, РОССИЯ \\ ${ }^{2}$ Научно-исследовательский институт строительной физики Российской академии архитектуры и строительных \\ наук, г. Москва, РОССИЯ
}

\begin{abstract}
Аннотация: Экспериментальные исследования и натурные испытания свидетельствуют о том, что воздействие агрессивных сред приводит к существенным изменениям физико-механических характеристик материалов конструкций. В статье предложена математическая модель позволяющая прогнозировать отрицательное воздействие агрессивных сред и оценивать долговечность изгибаемых конструкций.
\end{abstract}

Ключевые слова: физическая нелинейность, наведенная неоднородность, агрессивная среда, математическая модель, поверхностная коррозия, долговечность

Currently, in the design of thin-walled structures, there is a tendency to take into account real operating conditions, which leads to the complication of the mathematical models describing these structures. When designing the evolution of the life cycle of building structures, it is necessary to digitize a number of parameters for monitoring objects during operation, one of which is the durability of structures as a whole and their elements. This will avoid an unpredictable loss of their bearing capacity and will protect against more serious consequences. Durability can be considered as the life of the object as a whole, and its individual structural elements, and also allows you to determine the timing of scheduled preventive and overhaul.

Structural elements in the process of work interact with different working environments, as a result of which, during their operation, the intensity and nature of the distribution of the existing "working" loads changes over time. The structures are periodically exposed to the influence of environments that are aggressive in relation to the materials used. As a result, the aggressive 
components of the external environment diffusing into the surface layers of the construction material break the internal connections and lead to a change in the physical and mechanical characteristics of the material. As a rule, this means a decrease in its strength and deformation characteristics. By an aggressive working environment, we mean one, the impact of which on the construction material leads to the degradation of its strength and deformation characteristics. By degradation we mean the process of deterioration of the physical and mechanical parameters of the material relative to their initial (initial) values.

During the operation of the structure, the concentration of aggressive substances from the external environment in the material of the structure can change, accelerating the degradation of strength characteristics and the accumulation of irreversible scattered damage. The conditional line that delimits the main material of the structure from the material affected by the aggressive environment will be called the degradation front. The advance of the degradation front into the material of the structure makes it inhomogeneous (induced inhomogeneity), in connection with which there is a redistribution of stresses and strains in it. As a result, a dangerous state of the structure arises, by which we mean the achievement of stresses at one of the points of the structure equal to the value of the strength criterion used. The time from the start of operation of the structure to the onset of a dangerous state will be called the durability of the structure.

The intensity of the impact of an aggressive environment depends on its concentration in the volume of the construction material. With an increase in concentration, a noticeable decrease in the temporary resistance of the material and an increase in the degree of nonlinearity of the deformation curve are observed. The model becomes more complicated and along with other characteristics a "slow" time parameter appears. Therefore, in order to create mathematical models describing the work of a construction material in an aggressive environment, it is necessary to carry out additional experimental research. The integral characteristic reflecting the change in material properties is the deformation curve. It most fully reflects the processes occurring in the material, when interacting with an aggressive working environment. By changing the deformation diagram, one can judge the ultimate strength and deformation properties of the material, its ability to harden or soften, the degree of aggressiveness of the external environment in relation to the material under consideration.

The presence of a large number of parameters that affect the processes of interaction between the material of the structure and the aggressive working environment leads to the fact that the creation of a general mathematical model that would take into account all possible manifestations of the aggressive effect of the environment on the material is extremely difficult, and this is not connected only with the complexity of the theoretical description, but also with certain problems in the formulation of experiments. Therefore, it is necessary to use a phenomenological approach and develop particular calculation models. This will allow building mathematical models on the basis of experimental data, without requiring complete clarity in the content of those physicochemical processes that occur during the interaction of material and an aggressive working environment.

When creating mathematical models, it is assumed that there are deformation curves obtained when testing specific materials that interacted with an aggressive medium for different times at different levels of preloading. In this case, on the basis of the experimental results, it is possible to construct the physical equations of the mechanics of a deformable solid, taking into account the above features.

In this article, a mathematical model is built that describes the interaction of a structure material with an aggressive working environment (surface corrosion). When creating a model, we will use the method of structural parameters, which consists in the fact that a function $F(z, t)$ is introduced into the physical equations of the mechanics of a deformable solid body that allows us to take into 
account the change in the strength and deformation characteristics of the material within the affected layer, which we call degradation. The degradation function $F(z, t)$ depends on the concentration of the aggressive environment. To construct the resolving relations, we take the theory of small elastic-plastic deformations by A.A. Ilyushin. The influence of an aggressive environment has been taken into account by introducing a scalar function $F(z, t)$ into the physical equations to describe the degradation of the secant module in the affected layer of the structural material. As a result, the stress deviator tensor is as follows:

$$
D_{\sigma}=\frac{2}{3} F(z, t) E_{c} D_{\varepsilon}
$$

where, $D_{\sigma}$ - is stress deviator tensor, $D_{\varepsilon}-$ is strain deviator tensor, $E_{c}=\sigma_{i} / \varepsilon_{i}$-is secant module, $\sigma_{i}$ is stress intensity, $\varepsilon_{i}-$ is strain intensity.

As a result of the interaction of the construction material with an aggressive environment, the physical and mechanical parameters in the affected layer of the material changes over time according to the laws that are determined by the results of experiments. To the physical equations, it is necessary to add kinetic equations, which are a mathematical model of the change in time of one or another parameter of the structure or the material from which it is made. They do not describe the physical and chemical processes causing these changes. Since this article considers a mathematical model of surface corrosion destruction, the general form of the kinetic equation looks like this:

$$
\delta(t)=f(t)
$$

where $\delta(t)$ - is a depth of damaged layer, $t-$ is a time.

The kinetic equations are based only on hypotheses and assumptions of a phenomenological nature and are a mathematical formalization of the experimental data obtained, therefore, they should be distinguished by mathematical simplicity. The kinetic equations cannot pretend to be very general, and are suitable only for obtaining a reasonable approximation when describing a limited class of phenomena [1].

The theory of beams, plates and shells, complicated by the developing inhomogeneity of the physical and mechanical properties of the material, leads to the need to solve nonlinear differential equations in partial derivatives, taking into account the history of deformation of the material and the degradation of its mechanical characteristics, and the development of effective algorithms for the numerical implementation of the obtained equations.

Let us consider the problem of interaction of a plate made of a nonlinearly deformable material with an aggressive environment and construct a mathematical model that allows us to determine its durability.

To construct the resolving equation for the bending of a plate from a physically nonlinear material, we write expression (1) in an incremental form [1]:

$$
\frac{\Delta D_{\sigma}}{F}=\frac{2}{3}\left(E_{k} \Delta D_{\varepsilon}+E_{c} D_{\varepsilon} \frac{\Delta F}{F}\right),
$$

where $\Delta D_{\sigma}$ - is stress deviator tensor increment, $\Delta D_{\varepsilon}$ - is strain deviator tensor increment, $E_{k}-$ is tangent module, $\Delta F$ - is degradation function increment. Expanding expression (3), we obtain an incremental system of physical equations in the following form [1]:

$$
\begin{gathered}
\Delta \sigma_{x}=-\frac{4}{3} E_{k} z\left(\frac{\partial^{2} \Delta w}{\partial x^{2}}+\frac{1}{2} \frac{\partial^{2} \Delta w}{\partial y^{2}}\right)-\frac{4}{3} E_{c} z\left(\frac{\partial^{2} w}{\partial x^{2}}+\frac{1}{2} \frac{\partial^{2} w}{\partial y^{2}}\right) \frac{\Delta F}{F}, \\
\Delta \sigma_{y}=-\frac{4}{3} E_{k} z\left(\frac{\partial^{2} \Delta w}{\partial y^{2}}+\frac{1}{2} \frac{\partial^{2} \Delta w}{\partial x^{2}}\right)-\frac{4}{3} E_{c} z\left(\frac{\partial^{2} w}{\partial y^{2}}+\frac{1}{2} \frac{\partial^{2} w}{\partial x^{2}}\right) \frac{\Delta F}{F}, \\
\Delta \tau_{x y}=-\frac{2}{3} E_{k} z \frac{\partial^{2} \Delta w}{\partial x \partial y}-\frac{2}{3} E_{c} z \frac{\partial^{2} w}{\partial x \partial y} \frac{\Delta F}{F},
\end{gathered}
$$

where $\Delta w-$ is deflection increment, $w-$ is accumulated deflection, $\Delta \sigma_{x}, \Delta \sigma_{y}, \Delta \tau_{x y}-$ is increments of stress tensor components.

When deriving the resolving equation for the plate bending, we assume that the plate deflections are small in comparison with the plate thickness and the Kirchhoff's hypothesis of direct normals is valid. Thus, the incremental bending equation of a plate made of a physically nonlinear material in 
an aggressive working environment will take the following form [1]:

$$
\nabla^{2}\left(D_{k} \nabla^{2} \Delta w\right)-\frac{1}{2} L\left(D_{k}, \Delta w\right)=\Delta q-\Delta q_{\phi}^{*}
$$

where $\Delta q(x, y)$ - is distributed load increment, $\Delta q_{\phi}^{*}$ - is "Fictitious" load, reflecting the influence of an aggressive environment on the plate material, $D_{k}$ and $D_{c}^{*}$ are variables in the spatial coordinates of the plate stiffness, which have the following form:

$$
D_{k}=\frac{4}{3} \int_{-0.5 h}^{0.5 h} E_{k} z^{2} d z, \quad D_{c}^{*}=\frac{4}{3} \int_{-0.5 h}^{0.5 h} E_{c} z^{2} \frac{\Delta F}{F} d z .
$$

Differential operator $L\left(D_{k}, \Delta w\right)$ in the equation (5) has the form:

$$
L\left(D_{k}, \Delta w\right)=\frac{\partial^{2} D_{k}}{\partial x^{2}} \frac{\partial^{2} \Delta w}{\partial y^{2}}+\frac{\partial^{2} D_{k}}{\partial y^{2}} \frac{\partial^{2} \Delta w}{\partial x^{2}}-2 \frac{\partial^{2} D_{k}}{\partial x \partial y} \frac{\partial^{2} \Delta w}{\partial x \partial y} .
$$

Expression for " fictitious " load $\Delta q_{\phi}^{*}$ in the equation (5) has the following form:

$$
\Delta q_{\phi}^{*}=\nabla^{2}\left(D_{c}^{*} \nabla^{2} w\right)-\frac{1}{2} L\left(D_{c}^{*}, w\right) .
$$

When constructing a mathematical model of the interaction of a structure material with an aggressive working environment, the main task is to determine the type of degradation functions, the concentration of an aggressive environment and the kinetic equation. In order to obtain analytical expressions for the functions $F$ and $B$, consider Fig. $1[1,3]$.

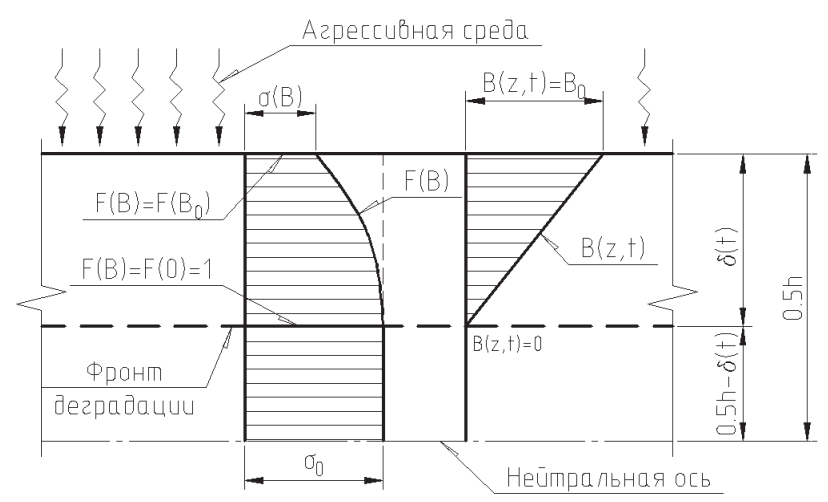

Figure 1. Interaction of the plate with an aggressive working environment
Based on experimental data and research results of other authors, let us assume that the degradation function has the form of an exponential [1, 2]:

$$
F(B(z, t))=\exp (-\lambda B(z, t))
$$

where $\lambda$ - parameter is experimental coefficient characterizing the degree of degradation of the deformation curve.

In general, to determine the concentration function of an aggressive medium, it is necessary to solve the mass transfer equation. Considering that, as a result of the interaction of the material of the structure and the aggressive working medium, the depth of penetration of the medium $\delta$ into the material of the structure is small compared to the thickness of the structure, it can be assumed that the change in the concentration of the aggressive medium occurs according to a linear law [1, 2]:

$$
B(z, t)=a(t) z+b(t),
$$

where $a(t), b(t)$ - are coefficients that are determined based on the conditions on the surface of the structure and on the boundary of the degradation front. We assume that on the surface of the structure at $z=0.5 h$, the concentration of the aggressive working medium $B(z, t)=B_{0}$ is considered constant throughout the entire interaction time, and the concentration of the medium at the boundary of the degradation front, that is, at $z=0.5 h-\delta$, is equal to zero $B(z, t)=$ 0 . Taking into account the above conditions, the function of concentration of an aggressive medium will take the following form:

$$
B(z, t)=B_{0} \frac{2|z|+2 \delta-h}{2 \delta} \quad \text { или } \quad B(z, t)=B_{0} \frac{|z|-z_{\phi \nu}}{0.5 h-z_{\phi \dot{ }}}
$$

Using functions (9) and (11), we obtain the ratio $\Delta F / F$

$$
\frac{\Delta F}{F}=-\lambda B_{0} \frac{h-2|z|}{2 \delta^{2}} \Delta \delta
$$

Substituting (12) into the expression of variable stiffness $D_{c}^{*}(6)$, after the necessary mathematical transformations, we obtain the expression for the "fictitious" load (8): 


$$
\Delta q_{\phi}^{*}=\frac{B_{0} \lambda h}{2 \delta^{2}} q(x, y) \Delta \delta .
$$

Let us give a method for determining the durability of a plate by the example of solving two problems. Consider two plates, square in plan, each of which is under the influence of a uniformly distributed load. The first plate is clamped along the entire contour, and the second has a hinge support along all edges. An aggressive medium is a $20 \%$ sodium hydroxide solution. The material of the plates is epoxy concrete [1, 2]. To solve the incremental differential equation (5), we use the BubnovGalerkin method. The depth of penetration of an aggressive medium (2) into the thickness of the material is calculated by the formula used by a number of authors:

$$
\delta(t)=\alpha \sqrt{t}
$$

where $\alpha$-is experimental coefficient equal 13.05 . $10^{-3} \mathrm{M} / 20 \partial$ (m/year).

The solution to equation (5) consists of two stages: at the first stage, a load $\Delta q$ is sequentially applied to the plate until the initial load $q=\Sigma \Delta q$ is reached; at the second stage, we take the increment in the thickness of the damaged layer $\Delta \delta$ as the

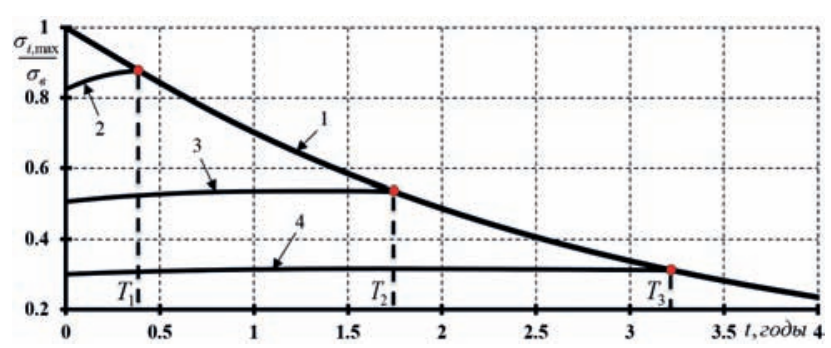

Figure 2. Determination of the durability of the plate rigidly clamped along the entire contour

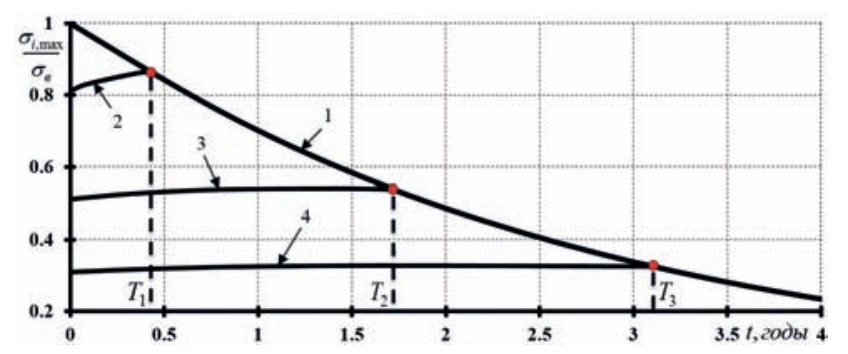

Figure 3. Determination of the longevity of the plate simply supported along the entire contour leading parameter, with $\delta=\Sigma \Delta \delta$. To implement the algorithm of the sequential loading method, the load is divided into 256 layers. The penetration of an aggressive medium into the thickness of the structure material is taken into account by the successive displacement of the degradation front into the plate material by the value $\Delta \delta=h / 256$. Below in Fig. Figures 2 and 3 show the results of determining the durability of a plate rigidly clamped along the entire contour (Fig. 2) and a plate simply supported along the entire contour (Fig. 3).

In fig. 2 and 3 the following designations are used: 1 - long-term strength curve; 2, 3, 4 - curves of the highest stress intensity in the plate $\sigma_{i, \max }$ at different levels of loading with a distributed load. For curves 2, 3 and 4, the aggressive environment began to act at loads equal to $80 \%, 50 \%$, and $30 \%$ of the ultimate load. The above calculation results allow us to determine the time of the onset of a dangerous state in the $T$ plates. A dangerous state is the point of intersection of the ascending curve 1 with curves 2, 3 and 4 . In fig. $2-T_{1}=0.39, T_{2}$ $=1.75$ and $T_{3}=3.22$. In fig. $3-T_{1}=0.43, T_{2}=$ 1.72 and $T_{3}=3.11$. It can be concluded that the boundary conditions insignificantly affect the longevity of the plate.

\section{REFERENCES}

1. Petrov V.V. Nelinejnaya inkremental'naya stroitel'naya mekhanika [Nonlinear Incremental Structural Mechanics]. Moscow, InfraInzheneriya, 2014, 480 pages (in Russian).

2. Petrov V.V., Ovchinnikov I.G., Shihov Yu.M. Raschet elementov konstrukcij, vzaimodejstvuyushchih s agressivnoj sredoj [Structural Analysis with Allowance for Aggressive Media]. Saratov, Izdatelstvo Saratovskogo universiteta, 1987, 288 pages (in Russian).

3. Petrov V.V., Mishchenko R.V. Ob odnoj modeli dolgovechnosti izgibaemyh konstrukcij [About one model of Long-Term Durability of Construction Materials, Products and Structures]. // Dolgovechnost' stroitel'nyh materialov, izdelij i konstrukcij: materialy 
Vseros. nauch.-tekhn. konf., posvyashch. 75-letiyu zasl. deyatelya nauki RF, akad. RAASN, d-ra tekhn. nauk, prof. Selyaeva V.P. (3-5 dek. 2019 g.). Saransk: Izd-vo Mordov. un-ta, 2019, pp. 250-257 (in Russian).

\section{СПИСОК ЛИТЕРАТУРЫ}

1. Петров В.В. Нелинейная инкрементальная строительная механика. - М.: Инфра-Инженерия, 2014. -480 с.

2. Петров В.В., Овчинников И.Г., Шихов Ю.М. Расчет элементов конструкций, вза- имодействующих с агрессивной средой. - Саратов: Издательство Саратовского университета, 1987. - 288 с.

3. Петров B.В., Мищенко Р.В. Об одной модели долговечности изгибаемых конструкций. // Долговечность строительных материалов, изделий и конструкций: материалы Всерос. науч.-техн. конф., посвящ. 75-летию засл. деятеля науки РФ, акад. РАACH, д-ра техн. наук, проф. Селяева В.П. (3-5 декабря 2019 года). - Саранск: Издательство Мордовского университета, 2019 , с. $250-257$.
Vladilen V. Petrov, Full Member of the Russian Academy of Architecture and Construction Sciences (RAACS), Professor, Dr. Sc., Head of the Department «Theory of Constructions and Building Structures», Yuri Gagarin State Technical University of Saratov; 410054, Russian Federation, Saratov, 77 Polytechnicheskaya; Tel. +7 (8452) 99-86-03; fax +7 (8452) 99-88-10; e-mail: vvp@ sstu.ru

Roman V. Mischenko, candidate of technical sciences, assistant of the department «Theory of Constructions and Building Structures» Yuri Gagarin State Technical University of Saratov; 410036, Saratov Region, Saratov, 38 Rostovskaya; Tel. +7(987) 338-40-22; e-mail: roman_ radon4@mail.ru

Dmitriy A. Pimenov, assistant of the department «Theory of Constructions and Building Structures» Yuri Gagarin State Technical University of Saratov; 410054, Saratov Region, Saratov, 97 2-nd Sadovaya; Tel. +7(937) 632-19-12; e-mail: scorpions91@inbox.ru
Петров Владилен Васильевич, академик Российской академии архитектуры и строительных наук (РААСН), профессор, доктор технических наук, заведующий кафедрой «Теория сооружений и строительных конструкций», Саратовский государственный технический университет имени Гагарина Ю.А.; 410054, Россия, г. Саратов, ул. Политехническая, 77; тел. +7(8452)99-86-03; факс +7(8452)99-88-10; e-mail: vvp@sstu.ru

Мищеенко Роман Викторович, кандидат технических наук, ассистент кафедры «Теория сооружений и строительных конструкций» Саратовского государственного технического университета им. Гагарина Ю.А.; 410036, Саратовская область, г. Саратов, ул. Ростовская, д. 38; тел. +7(987)338-40-22; e-mail: roman_radon4@mail.ru

Пименов Дмитрий Алексеевич, ассистент кафедры «Теория сооружений и строительных конструкций» Саратовского государственного технического университета им. Гагарина Ю.А.; 410054, Саратовская область, г. Саратов, ул. 2-я Садовая, д. 97; тел. +7(937)632-19-12; e-mail: scorpions91@inbox.ru 